\title{
Potential treatments for COVID-19 \\ are not parachutes - avoiding a pandemic of medical reversals
}

\author{
Alison Felipe Alencar Chaves ${ }^{1}$ (i) \\ Felipe Nogueira ${ }^{2}$ (1)
}

${ }^{1}$ Corresponding author. PhD in Department of Microbiology, Immunology and Parasitology (São Paulo). São Paulo, Brazil. felipealison@gmail.com ${ }^{2}$ PhD in Medical Science (Rio de Janeiro). Rio de Janeiro, Brazil. felipenogueira@gmail.com

Brazil is steadily scaling up the number of Covid-19 cases. Confirmed cases are over the three million and deaths surpass $100,000^{1}$. The chloroquine/ hydroxychloroquine has been nationally regarded as a guarantee of success against the pandemic. However, the results of preclinical ${ }^{2}$ and well conducted randomized trials show no efficacy in post-exposure prophylaxis ${ }^{3}$, in outpatients with early Covid-19ㄴ, 4 or in hospitalized patients ${ }^{5}$. Indeed, the position contrary to the use of these medications had already resulted in the ousting out two Health Ministers and has been the source of endless polemics in the country ${ }^{6}$. Brazilian physicians are prescribing the most varied schemes using hydroxychloroquine, nitazoxanide, ivermectin, or corticosteroids ${ }^{7-9}$. It is important to reason about the interventions that have been adopted for the clinical management of COVID-19 in Brazil. In order to do that, we remind a systematic review ${ }^{10}$ which revealed that the clinical perception of the effect of medical interventions is extremely inaccurate: physicians tend to overestimate the benefit and underestimate the harms of their interventions. That would create a professional culture in which the physician would have to do anything, in which waiting and not doing something would not be valid options. As such, professionals often try to justify the conduct precisely because of the lack of evidence, arguing that there is no evidence for everything nor time to gather evidence ${ }^{11}$.

An emblematic systematic review aimed to assess whether there was evidence for the use of parachutes during a gravitational challenge ${ }^{12}$. The study concluded that randomized controlled trials (RCTs) have never been conducted to provide evidence of the benefit of using parachutes in a free fall situation. The idea is that there are situations that cannot be subjected to the rigors of an RCT as it would be unethical to randomize individuals to receive or not a parachute before a situation of free fall. It is a study that simply cannot be done for ethical reasons and it is obvious that those without parachutes would die. Many health professionals are now using a similar argument to justify the absence of evidence for their conduct, especially in infectious diseases ${ }^{13}$. But can most medical interventions be correctly compared with the parachute situation? The answer is a categorical "no". In 2018, investigators found that interventions considered by physicians 
as beneficial as parachutes do not satisfy the impediment conditions to run an RCT. Furthermore, for most conducts, RCTs have been developed and published, some with evidence against the conduct ${ }^{14}$.

While considering interventions to treat the acute respiratory distress syndrome (ARDS) caused by SARS-Cov-2 the shreds of evidence supporting the use of corticosteroids are sparse, but we already know that the benefit is absent when ARDS is caused by other conditions ${ }^{15,16}$. Is there a good reason to think that ARDS caused by SARS-CoV-2 will respond in a different way? The Recovery trial17 suggests that a low dose of dexamethasone can reduce mortality with an overall relative risk reduction of $13 \%$. Patients requiring mechanical ventilation or supplemental oxygen benefited from the intervention while individuals who were not in oxygen supplementation did not. Interestingly, this finding is in line with the use of corticosteroids in community-acquired pneumonia ${ }^{18}$, where the drug reduces mortality in severe cases but not in mild ones.

On the other hand, Remdesivir has only a marginal effect, if any, in the reduction of mortality ${ }^{19,20}$ and has been proposed as a costly compassionate therapy. Yet, a bunch of suggestions of repurposing drugs like hydroxychloroquine, ivermectin, or nitazoxanide are under investigation in tiny trials with very low statistical power 21,22 . Looking at the sample size of these studies combined with extensive use of surrogate endpoints instead of clinical ones causes concerns that the results could cause more confusion than offer any response to the pandemic. We could be about to experience the beginning of a new wave of medical reversals ${ }^{23}$ because of the pandemic. It is the case for hydroxychloroquine, which was approved by FDA (through Emergency Authorization Use Act) and by the Brazilian government as an essential drug to treat COVID-19, even though there were no RCT demonstrating any benefit of the drug for viral infections at al. Indeed, a recently published trial ${ }^{\underline{3}}$ demonstrated that hydroxychloroquine was not able to offer prophylactic benefit to people with a high risk of exposure to the virus. Ultimately, the Recovery trial found no difference in 28-day mortality between the hydroxychloroquine and usual care arms $^{5}$ and the National Institutes of Health's trial was halted due to lack of efficacy ${ }^{24}$. After the publication of negative results, agencies like the FDA have decided to suspend the recommendation to use the drug to treat COVID-19. In reality, such a recommendation should have never been made in the first place.

Indeed, there is no such thing as a dichotomy between offering an intervention without evidence or to offer nothing in order to treat a patient on the course of a pandemic. At a more general framework, the standard of care applicable to a patient with acute respiratory distress syndrome based on lungprotective ventilation ${ }^{25}$ and the old practices like prone positioning the patient is able to offer an actual reduction in mortality ${ }^{26}$. The argument that the pandemic is an atypical situation as the reason why physicians should try everything is simply a euphemism to practice medicine without evidence. It is not a scientific attitude. We still need wellconducted RCTs and we urgently need to stop adopting conducts without good evidence under the excuse of a pandemic or any other adverse scenario. The recommended interventions to treat patients with Covid-19 are not akin to parachutes and we need not to make this a pandemic of medical reversals

\section{Author contributions}

Chaves AFA wrote the first version of the manuscript. Nogueira F reviewed and offered important intellectual contributions. Both authors read the final version and agreed for publication.

\section{Competing interests}

No financial, legal or political competing interests with third parties (government, commercial, private foundation, etc.) were disclosed for any aspect of the submitted work (including but not limited to grants, data monitoring board, study design, manuscript preparation, statistical analysis, etc.).

\section{References}

1. Dong E, Du H, Gardner L. An interactive web-based dashboard to track COVID-19 in real time. Lancet Infect Dis. 2020;20(5):533-4. doi: 10.1016/S1473-3099(20)30120-1

2. Maisonnasse P, Guedj J, Contreras V, Behillil S, Solas C, Marlin $R$ et al. Hydroxychloroquine use against SARS-CoV-2 infection in non-human primates. Nature. 2020. doi: 10.1038/s41586-0202558-4 
3. Boulware DR, Pullen MF, Bangdiwala AS, Pastick KA, Lofgren SM, Okafor EC et al. A Randomized Trial of Hydroxychloroquine as Postexposure Prophylaxis for Covid-19. N Engl J Med. 2020. doi: 10.1056/NEJMoa2016638

4. Skipper CP, Pastick KA, Engen NW, Bangdiwala AS, Abassi M, Lofgren SM et al. Hydroxychloroquine in Nonhospitalized Adults With Early COVID-19. Ann Intern Med. 2020. doi: 10.7326/M204207

5. Horby P, Mafham M, Linsell L, Bell JL, Staplin N, Emberson JR et al. Effect of Hydroxychloroquine in Hospitalized Patients with COVID-19: Preliminary results from a multi-centre, randomized, controlled trial. medRxiv. 2020. doi: 10.1101/2020.07.15.20151852

6. Fraser B. 'Medications should be prescribed by doctors, not the president': leading Brazilian scientist discusses the pandemic. Nature. 2020. doi: 10.1038/d41586-020-01506-2

7. Valfré V. Crise aumenta venda de remédios sem eficácia comprovada contra coronavirus. Estadão [Internet]. 2020. Available at: https://saude.estadao.com.br/noticias/geral,criseaumenta-venda-de-remedios-sem-eficacia-comprovada-contracoronavirus, 70003289502

8. Tajra A. Unimed Brusque envia kit com cloroquina para médicos como "profilaxia”. UOL Notícias [Internet]. 2020. Available at: https://noticias.uol.com.br/saude/ultimas-noticias/ redacao/2020/07/19/cloroquina-unimed-kit-covid.htm

9. Moreira J. Covid-19: unidades de referência registram entrega de mais de 2 mil kits de medicamentos em 24 horas [Internet]. 2020. Available at: http://macapa.ap.gov.br/ coronavirus/2020/06/04/covid-19-unidades-de-referenciaregistram-entrega-de-mais-de-2-mil-kits-de-medicamentos-em24-horas/

10. Hoffmann TC, Mar CD. Clinicians' Expectations of the Benefits and Harms of Treatments, Screening, and Tests: A Systematic Review. JAMA Intern Med. 2017;177(3):407-419. doi: 10.1001/ jamainternmed.2016.8254

11. Keane M. CoViD-19: Time to rethink the RCT and consider more efficient and ethical approaches to clinical knowledge acquisition. Journal of Medical Ethics [Internet]. 2020. Available at: https://blogs.bmj.com/medical-ethics/2020/07/08/covid-19time-to-rethink-the-rct-and-consider-more-efficient-and-ethicalapproaches-to-clinical-knowledge-acquisition/

12. Smith GCS, Pell JP. Parachute use to prevent death and major trauma related to gravitational challenge: systematic review of randomised controlled trials. BMJ. 2003;327(7429):1459-1461. doi: 10.1136/bmj.327.7429.1459

13. Lagier JC, Raoult D. Deadly infectious diseases such as Ebola: the parachute paradigm. Clin Microbiol Infect. 2015; 21:389-390. doi: $10.1016 /$ j.cmi.2015.02.027
14. Hayes MJ, Kaestner V, Mailankody S, Prasad V. Most Medical Practices Are Not Parachutes: A Citation Analysis of Practices Felt by Biomedical Authors to Be Analogous to Parachutes. CMAJ Open. 2018;6(1):31-38. doi: 10.9778/cmajo.20170088

15. Zhou Y, Fu X, Liu X, Huang C, Tian G, Ding C et al. Use of corticosteroids in influenza-associated acute respiratory distress syndrome and severe pneumonia: a systemic review and metaanalysis. Sci Rep. 2020;10(1):3044. doi: 10.1038/s41598-020$\underline{59732-7}$

16. Adhikari N, Burns KEA, Meade MO. Pharmacologic therapies for adults with acute lung injury and acute respiratory distress syndrome. Cochrane Database Syst Rev. 2004;2004(4):CD004477. doi: 10.1002/14651858.CD004477.pub2

17. Horby P, Lim WS, Emberson JR, Mafham M, Bell JL, Linsell $L$ et al. Dexamethasone in Hospitalized Patients with Covid-19 - Preliminary Report. N Engl J Med. 2020. doi: $10.1056 /$ NEJMoa2021436

18. Stern A, Skalsky K, Avni T, Carrara E, Leibovici L, Paul M. Corticosteroids for pneumonia. Cochrane Database Syst Rev. 2017(12):CD007720. doi: 10.1002/14651858.CD007720.pub3

19. Wang Y, Zhang D, Du G, Du R, Zhao J, Jin Y et al. Remdesivir in adults with severe COVID-19: a randomised, double-blind, placebo-controlled, multicentre trial. Lancet. 2020;395(10236):1569-78. doi: 10.1016/S0140-6736(20)31022-9

20. Beigel JH, Tomashek KM, Dodd LE, Mehta AK, Zingman BS, Kalil AC et al. Remdesivir for the Treatment of Covid-19 - Preliminary Report. N Engl J Med. 2020. doi: 10.1056/NEJMoa2007764

21. ClinicalTrials.gov. Efficacy and Safety of Nitazoxanide for the Treatment of Hospitalized Patients With Moderate COVID-19 [Internet]. 2020. Available at: https://clinicaltrials.gov/ct2/show/ NCT04348409?term=nitazoxanide\&cond=Covid19\&draw $=2$

22. Glasziou PP, Sanders S, Hoffmann T. Waste in covid-19 research. BMJ. 2020;369:1847. doi: 10.1136/bmj.m1847

23. Prasad V, Cifu A. Medical reversal: why we must raise the bar before adopting new technologies. Yale J Biol Med. 2011;84(4):471-8.

24. Kiley JP. NIH halts clinical trial of hydroxychloroquine [Internet]. 2020. Available at: https://www.nih.gov/news-events/ news-releases/nih-halts-clinical-trial-hydroxychloroquine

25. Petrucci N, Lacovelli W. Lung Protective Ventilation Strategy for the Acute Respiratory Distress Syndrome. Cochrane database Syst Rev. 2007;(3):CD003844. doi: 10.1002/14651858.CD003844.pub3

26. Guérin C, Reignier J, Richard J-C, et al. Prone Positioning in Severe Acute Respiratory Distress Syndrome. N Engl J Med. 2013;368(23):2159-68. Available at: doi: 10.1056/NEJMoa1214103 